
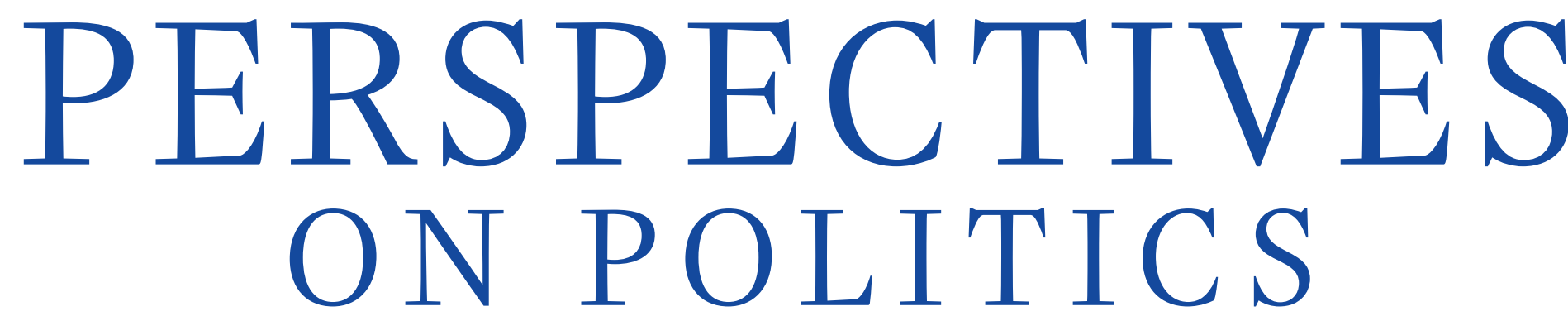

A Political Science Public Sphere | September 2018, Volume 16, Number 3

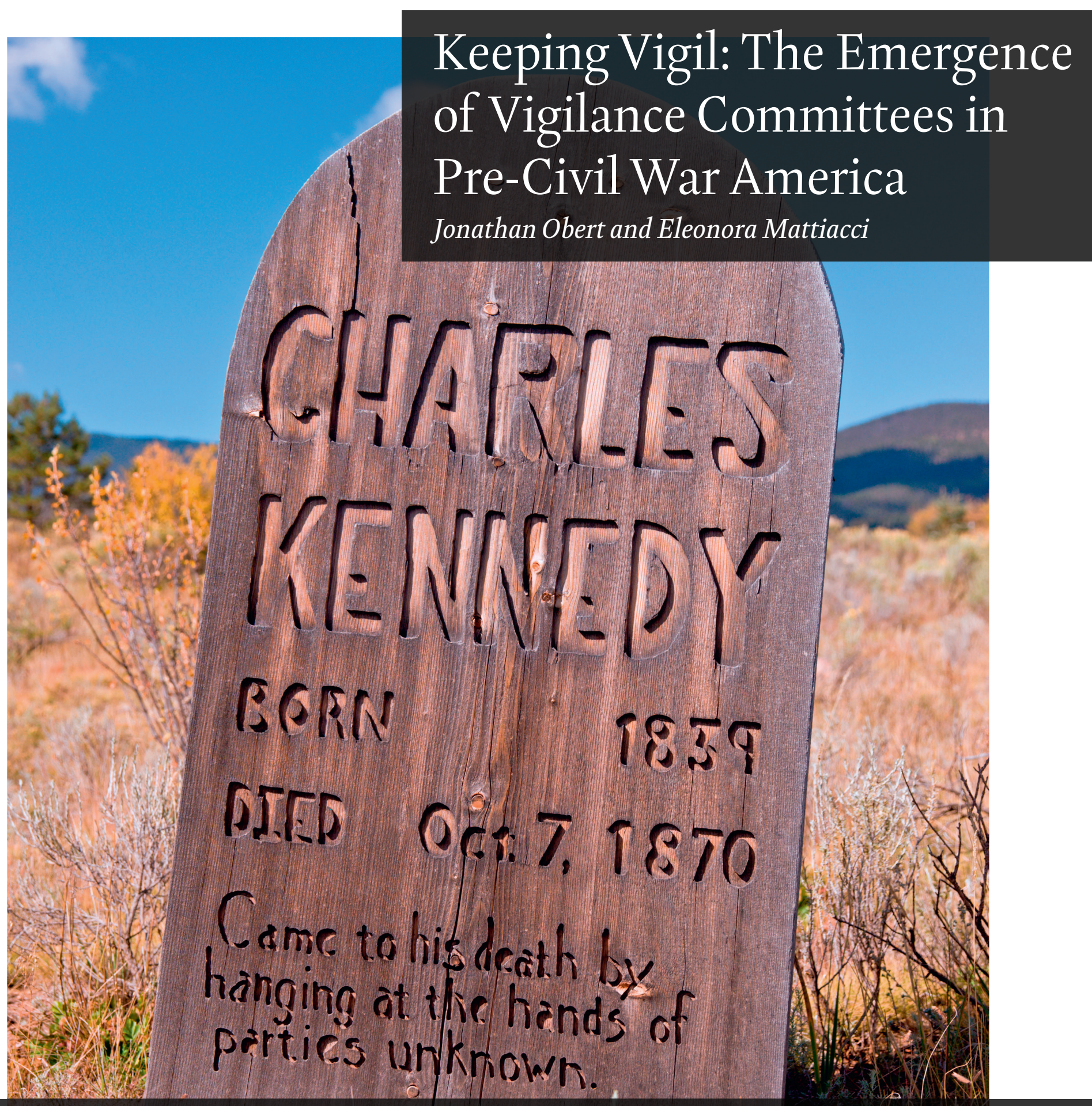

Special Section: The Persistence of Authoritarianism 


\section{Call for Editor(s)}

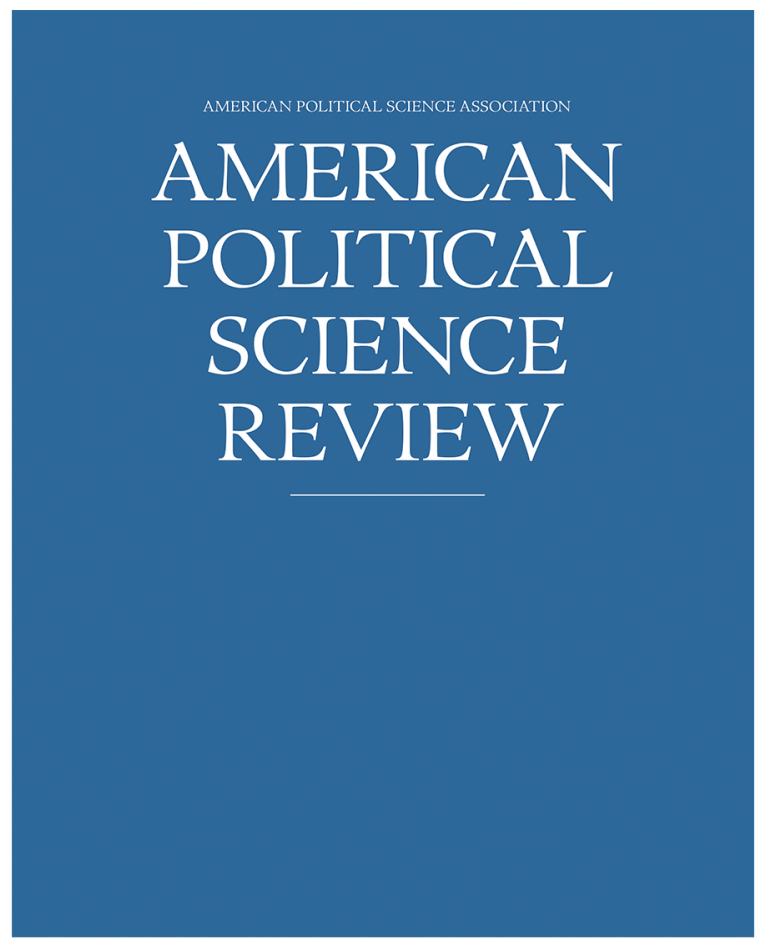

\section{Applications due October 31, 2018}

For more information visit

\section{www.apsanet.org/apsr}

Attend the Search Panel at the 2018 Annual Meeting

Thursday, Aug. 30, 4:00-5:30pm, Hynes 204

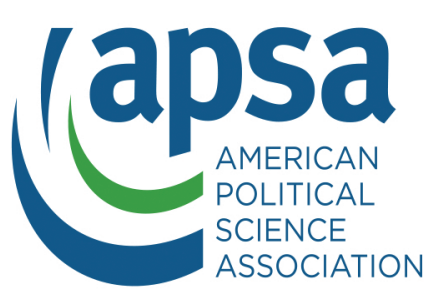




\section{Perspectives on Politics}

September 2018/Vol. 16, No. 3 | American Political Science Association

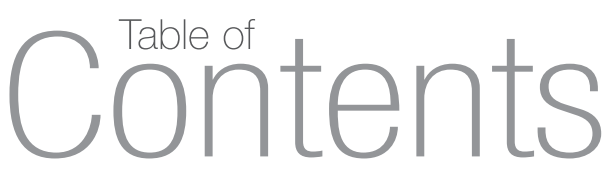

\section{From the Editors}

595 The Persistence of Authoritarianism Michael Bernhard and Daniel I. O'Neill

\section{Articles}

600 Keeping Vigil: The Emergence of Vigilance Committees in Pre-Civil War America Jonathan Obert and Eleonora Mattiacci

617 When Do the Dispossessed Protest? Informal Leadership and Mobilization in Syrian Refugee Camps

Killian Clarke

634 Democratic Waves in Historical Perspective Seva Gunitsky

\section{Special Section: The Persistence of Authoritarianism}

652 Legitimacy in Autocracies: Oxymoron or Essential Feature? Johannes Gerschewski

666 Domination and Disobedience: Protest, Coercion and the Limits of an Appeal to Justice

Guy Aitchison

680 "Thugs-for-Hire": Subcontracting of State Coercion and State Capacity in China Lynette H. Ong

696 Race, Religion, or Culture? Framing Islam between Racism and Neo-Racism in the Online Network of the French Far Right

Caterina Froio

710 How and Why Armed Groups Participate in Elections Aila M. Matanock and Paul Staniland

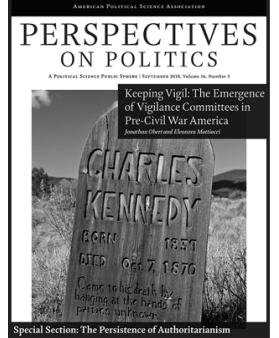

Cover Art: A dire warning to scofflaws who transgress on the laws of the wild west, in Elizabethtown Cemetery, New Mexico. M L Pearson / Alamy Stock Photo. 


\section{Reflections}

728 Transparency and Integrity in Conducting Field Research on Politics in Challenging Contexts Aili Mari Tripp

739 Subjects and Scholars' Views on the Ethics of Political Science Field Experiments Scott Desposato

\section{The Book Review Section}

\section{Book Review Essays}

751 Explaining Violence Against Non-Combatants in Civil War Jeffrey Kopstein

755 The Many Individuals of the Liberal and Democratic Traditions Brendon Westler

\section{Book Symposium}

760 A Discussion of Claire L. Adida, David D. Laitin, and Marie-Anne Valfort's Why Muslim Integration Fails in Christian-Heritage Societies

Abdulkader Sinno

Amaney Jamal

Anne Norton

\section{Critical Dialogues}

767 Reviews and Responses

Charles W. Mills

Black Rights/White Wrongs:

The Critique of Racial Liberalism

773 Reviews and Responses

Dara Kay Cohen

Rape During Civil War
Juliet Hooker

Theorizing Race in the Americas:

Douglass, Sarmiento, Du Bois, and Vasconcelos

Kerry F. Crawford

Wartime Sexual Violence: From

Silence to Condemnation

of a Weapon of War

Lawrence R. Jacobs and Desmond King Fed Power: How Finance Wins

Stephen C. Nelson

The Currency of Confidence: How Economic Beliefs Shape the IMF's

Relationship with Its Borrowers 
791 Reviews and Responses

Don Herzog

Defaming the Dead

796 Reviews and Responses

B. Dan Wood and Soren Jordan

Party Polarization in America: The War Over

Two Social Contracts

802 Reviews and Responses

Avery Kolers

A Moral Theory of Solidarity
Simon Stow

American Mourning: Tragedy, Democracy, Resilience

\section{Sam Rosenfeld}

The Polarizers: Postwar Architects of Our Partisan Era

\section{Mara Marin}

Connected by Commitment: Oppression and Our Responsibility to Undermine It

\section{Craig M. Kauffman}

Grassroots Global Governance: Local Watershed Management Experiments and the Evolution of Sustainable Development

and Social Justice in India, Tanzania, and Mexico

\section{Book Reviews}

\section{POLITICAL THEORY}

813 Stuart Gray, A Defense of Rule: Origins of Political Thought in Greece and India. Review by Melissa Lane

814 Ryan Patrick Hanley, Love's Enlightenment: Rethinking Charity in Modernity. Review by David Lay Williams

815 William E. Connolly, Aspirational Fascism: The Struggle for Multifaceted Democracy under Trumpism. Review by Jeffrey C. Isaac

818 Burke A. Hendrix and Deborah Baumgold, eds, Colonial Exchanges: Political Theory and the Agency of the Colonized. Review by Adom Getachew

819 Linda M. G. Zerilli, A Democratic Theory of Judgment. Review by Ronald Beiner

821 Michael Allen Gillespie, Nietzsche's Final Teaching. Review by Joshua Foa Dienstag

Heath Fogg Davis, Beyond Trans: Does Gender Matter? Review by Lorna Bracewell

824 Jill Frank, Poetic Justice: Rereading Plato's Republic. Review by John R. Wallach

Vickie B. Sullivan, Montesquieu and the Despotic Ideas of Europe: An Interpretation of the Spirit of the Laws. Review by Michael Mosher

828 Joshua Simon, The Ideology of Creole Revolution: Imperialism and Independence in American and Latin American Political Thought. Review by Angélica Maria Bernal

830 Jade Larissa Schiff, Burdens of Political Responsibility: Narrative and the Cultivation of Responsiveness. Review by Manu Samnotra

831 Ange-Marie Hancock, Intersectionality: An Intellectual History. Review by Lisa García Bedolla

832 Isabelle Ferreras, Firms as Political Entities: Saving Democracy Through Economic Bicameralism. Review by Abraham Singer

834 Matthew J. Walton, Buddhism, Politics and Political Thought in Myanmar. Review by Tun Myint

836 Kate Elizabeth Brown, Alexander Hamilton and the Development of American Law.

Jack N. Rakove, A Politician Thinking: The Creative Mind of James Madison. Review by Clement Fatovic 
AMERICAN POLITICS

838 Richard A. Posner, The Federal Judiciary: Strengths and Weaknesses. Review by Mariano-Florentino Cuéllar

840 C. Danielle Vinson, Congress and the Media: Beyond Institutional Power. Review by Ryan J. Vander Wielen

842 Daniel E. Ponder, Presidential Leverage: Presidents, Approval, and the American State. Review by Jennifer L. Selin

843 William W. Franko and Christopher Witko, The New Economic Populism: How States Respond to Economic Inequality. Review by Jacob S. Hacker

844 Heather Silber Mohamed, The New Americans? Immigration, Protest, and the Politics of Latino Identity.

Chris Zepeda-Millán, Latino Mass Mobilization: Immigration, Racialization, and Activism. Review by John A. Garcia

847 Donald R. Kinder and Nathan P. Kalmoe, Neither Liberal nor Conservative: Ideological Innocence in the American Public. Review by Samara Klar

David Lowery, Darren Halpin, and Virginia Gray, The Organization Ecology of Interest Communities: Assessment and Agenda. Review by Peter L. Francia

Matthew S. Shugart and Rein Taagepera, Votes from Seats: Logical Models of Electoral Systems. Review by Michael D. McDonald

851 Manlio Graziano, In Rome We Trust: The Rise of Catholics in American Political Life.

Mark A. Smith, Secular Faith: How Culture Has Trumped Religion in American Politics. Review by Laura R. Olson

Lawrence Baum, David Klein, and Matthew J. Streb, The Battle for the Court: Interest Groups, Judicial Elections, and Public Policy. Review by Anthony Champagne

Andrew R. Lewis, The Rights Turn in Conservative Christian Politics: How Abortion Transformed the Culture Wars. Review by Deborah R. McFarlane

Susan Gluck Mezey, Beyond Marriage: Continuing Battles for LGBT Rights.

Daniel R. Pinello, America's War on Same-Sex Couples and Their Families: And How the Courts Rescued Them. Review by Clyde Wilcox

857 Douglas E. Edlin, Common Law Judging: Subjectivity, Impartiality, and the Making of Law. Review by Ken I. Kersch

859 Timothy M. LaPira and Herschel F. Thomas, Revolving Door Lobbying: Public Service, Private Influence, and the Unequal Representation of Interests. Review by Clare R. Brock

860 Marc Morjé Howard, Unusually Cruel: Prisons, Punishment, and the Real American Exceptionalism. Review by Daniel S. Moak

862 Raymond J. La Raja and Brian F. Schaffner, Campaign Finance and Political Polarization: When Purists Prevail. Review by Seth Masket

864 Greg Goelzhauser, Choosing State Supreme Court Justices: Merit Selection and the Consequences of Institutional Reform.

Review by Meghan E. Leonard

\section{COMPARATIVE POLITICS}

865 Gretchen Helmke, Institutions on the Edge: The Origins and Consequences of Inter-Branch Crises in Latin America. Review by Eduardo Alemán

Miguel A. Centeno, Atul Kohli, Deborah J. Yashar, and Dinsha Mistree, States in the Developing World. Review by Rachel Sigman

868 Jesse Driscoll, Warlords and Coalition Politics in Post-Soviet States. Review by William Reno

Milan Vaishnav. When Crime Pays: Money and Muscle in Indian Politics. Review by Vineeta Yadav

871 Regine A. Spector, Order at the Bazaar: Power and Trade in Central Asia. Review by Noah Coburn

873 William T. Daniel, Career Behaviour and the European Parliament: All Roads Lead Through Brussels?

Patrik Öhberg, Ambitious Politicians: The Implications of Career Ambition in Representative Democracy. Review by Nikoleta Yordanova

Erica S. Simmons, Meaningful Resistance: Market Reforms and the Roots of Social Protest in Latin America. Review by Moises Arce 
876 Jonathan Bach, What Remains: Everyday Encounters with the Socialist Past in Germany. Review by Jenny Wüstenberg

877 Bethany Lacina, Rival Claims: Ethnic Violence and Territorial Autonomy under Indian Federalism. Review by Sumit Ganguly

878 Dorle Hellmuth, Counterterrorism and the State: Western Responses to 9/11. Review by Peter Romaniuk

879 Taylor C. Boas, Presidential Campaigns in Latin America: Electoral Strategies and Success Contagion. Review by Chiara Superti

881 Carly Elizabeth Schall, The Rise and Fall of the Miraculous Welfare Machine: Immigration and Social Democracy in Twentieth-Century Sweden. Review by Maureen A. Eger

883 Thomas Edward Flores and Ifran Nooruddin, Elections in Hard Times: Building Stronger Democracies in the 21st Century. Review by Staffan I. Lindberg

884 Eduardo Alemán and George Tsebelis, Legislative Institutions and Lawmaking in Latin America. Review by Valeria Palanza

886 Chi Adanna Mgbako, To Live Freely in This World: Sex Worker Activism in Africa. Review by Samantha Majic

\section{INTERNATIONAL RELATIONS}

887 Cynthia Roberts, Leslie Elliott Armijo, and Saori N. Katada, The BRICS and Collective Financial Statecraft. Review by Miles Kahler

Kimi Lynn King and James David Meernik, The Witness Experience: Testimony at the ICTY and Its Impact. Review by Jelena Subotic

890 Brantly Womack, Asymmetry and International Relationships. Review by T. V. Paul

Jason Dittmer, Diplomatic Material: Affect, Assemblage, and Foreign Policy.

Stefanie R. Fishel, The Microbial State: Global Thriving and the Body Politic. Review by Ty Solomon

Brent Durbin, The CIA and the Politics of US Intelligence Reform. Review by John A. Gentry

894 Aseema Sinha, Globalizing India: How Global Rules and Markets Are Shaping India's Rise to Power. Review by Surupa Gupta

896 Mark T. Buntaine, Giving Aid Effectively: The Politics of Environmental Performance and Selectivity at Multilateral Development Banks.

Daniel McDowell, Brother, Can You Spare a Billion? The United States, the IMF, and the International Lender of Last Resort.

Review by Takaaki Masaki

Laura Sjoberg, Women as Wartime Rapists: Beyond Sensation and Stereotyping. Review by Elisabeth Jean Wood

899 Jonathan Renshon, Fighting for Status: Hierarchy and Conflict in World Politics. Review by Barry O'Neill

900 Loch K. Johnson, Spy Watching: Intelligence Accountability in the United States. Review by Joshua Rovner

902 J. C. Sharman, The Despot's Guide to Wealth Management: On the International Campaign against Grand Corruption. Review by Mlada Bukovansky

904 Gary Goertz, Paul F. Diehl, and Alexandru Balas, The Puzzle of Peace: The Evolution of Peace in the International System. Review by Reşat Bayer

Kelly M. Greenhill and Peter Krause, eds, Coercion: The Power to Hurt in International Politics. Review by Dianne Pfundstein Chamberlain

906 Stephan Haggard and Marcus Noland, Hard Target: Sanctions, Inducements, and the Case of North Korea. Review by Zachary Selden

908 Alexandra Guisinger, American Opinion on Trade: Preferences Without Politics. Review by I. M. (Mac) Destler

910 Review Index

913 Corrigendum 


\section{Philosophy of Perspectives on Politics}

Perspectives seeks to nurture a political science public sphere, publicizing important scholarly topics, ideas, and innovations, linking scholarly authors and readers, and promoting broad reflexive discussion among political scientists about the work that we do and why this work matters.

A full-length copy of the journal's editorial philosophy appears in Perspectives on Politics 8(1): 7-10 and also on the web at http://www.apsanet.org/content_44375.cfm.

\section{Submission and Review}

For submission guidelines, please see http://www.apsanet.org/content_44360.cfm.

Our editorial team discusses all submissions. Those that seem promising are evaluated by several external reviewers - with full confidentiality on both sides - and then accepted, returned for further revisions, or declined with suggestions of more appropriate venues for publication.

\section{CONTACT INFO}

Perspectives on Politics

Department of Political Science

1507 W. University Avenue

PO Box 117325 Anderson Hall

University of Florida

Gainesville, FL 32611

Perspectives: perspectives@apsanet.org

Book Reviews: perspectives-reviews@polisci.ufl.edu

\section{Perspectives on Politics}

\section{Editor}

Michael Bernhard, University of Florida, 2017

Associate Editor and Book Review Editor

Daniel I. O'Neill, University of Florida, 2017-

Managing Editor

Jennifer C. Boylan, University of Florida, 2017

Assistants to the Editor

$\begin{array}{ll}\text { Alec Dinnin } & \text { Dragana Svraka } \\ \text { Karla Mundim } & \text { Saskia van Wees } \\ \text { Nicholas Rudnik } & \\ \text { Marah Schlingensiepen }\end{array}$

Marah Schlingensiepen

Editors Emeritus

Jeffrey C. Isaac, Indiana University, 2009-2017

James Johnson, University of Rochester, 2005-2008

Jennifer Hochschild, Harvard University, 2002-2005

Editorial Board

Resat Bayer, Koç University

Cristina Beltran, New York University

Nancy Bermeo, Oxford University

Charli Carpenter, University of Massachusetts, Amherst

Simone Chambers, University of California, Irvine

Katherine Cramer, University of Wisconsin-Madison

Henry Farrell, George Washington University

Archon Fung, Harvard University

Anna Grzymala-Busse, Stanford University

Michael Hanchard, University of Pennsylvania

Ange-Marie Hancock, University of Southern California

Mala Htun, University of New Mexico

Bryan Jones, University of Texas, Austin

Daniel Kapust, University of Wisconsin-Madison

Mary Fainsod Katzenstein, Cornell University

Douglas Lemke, Penn State University

Julia Lynch, University of Pennsylvania

Marc Lynch, George Washington University

Samantha Majic, John Jay College, CUNY

Jørgen Møller, Aarhus University

Cas Mudde, University of Georgia

Daniel Nexon, Georgetown University

Erin O'Brien, University of Massachusetts, Boston

Paul Pierson, University of California, Berkeley

Andrew Sabl, Yale University

Ed Schatz, University of Toronto

Joe Soss, University of Minnesota

Paul Staniland, University of Chicago

Joan C. Tronto, University of Minnesota

Ashutosh Varshney, Brown University

Vesla Weaver, Yale University

Deborah J. Yashar, Princeton University

Cyrus Ernesto Zirakzadeh, University of Connecticut

vi Perspectives on Politics
Association Office Address and Membership Information: American Political Science Association individual membership dues are as follow: Regular members with income $\$ 200,000$ + $\$ 325 ; \$ 135,000-\$ 199,999, \$ 276 ; \$ 100,000-\$ 134,000$, \$246; \$80,000-\$99,999, \$212; \$60,000-\$79,999, \$191: $\$ 50,000-\$ 59,999, \$ 175 ; \$ 40,000-\$ 49,999$, $\$ 145$; less than $\$ 40,000, \$ 98$; Retired members with income $\$ 25,000+, \$ 66$ Retired members with income less than $\$ 25,000$, \$40; Targeted international member (TIM), \$45; Life member, \$4,000; high school teacher (PS only), \$50: Unemployed members, \$45: Student members, \$52; Associate member with one journal selection, $\$ 75$. The amount of the dues allocated for a subscription is $\$ 5.75$ for an individual membership. Changes of address for members should be completed online or mailed to the APSA membership office at: APSA, 1527 New Hampshire Avenue N.W., Washington, DC 20036.

Subscription, Publishing, and Advertising Office Address: Cambridge University Press, One Liberty Plaza, Floor 20, New York, NY 10006; and (for correspondents outside the United States, Canada, and Mexico) Cambridge University Press, Journals Fulfillment Department, UPH, Shaftesbury Road,

Cambridge CB2 8BS, England.

Subscription Information: Perspectives on Politics (ISSN 15375927) is published quarterly, in March, June, September, and December, by Cambridge University Press for the American Political Science Association. Annual institutional electronic-only subscription rate (2018) is US\$1642 in the United States, Canada, and Mexico; £943 elsewhere. Annual institutional print and electronic subscription rate (2018) is US\$1903 in the United States, Canada and Mexico; £1080 elsewhere. Perspectives on Politics is sold only as part of a joint subscription with the American Political Science Review and PS: Political Science \& Politics. Single part rate (2018) is US\$182 in the United States, Canada, and Mexico; $£ 104$ elsewhere Periodicals postage rate paid at New York, NY, and additional mailing offices.

Postmaster: Send address changes to Perspectives on Politics, Cambridge University Press, One Liberty Plaza, Floor 20 New York, NY 10006, U.S.A

(c) American Political Science Association 2018

All rights reserved. No part of this publication may be reproduced, in any form or by any means, electronic, photocopying, or otherwise, without permission in writing from Cambridge University Press. Policies, request forms, and contacts are available from: http://www.cambridge.org/rights/permissions/ permission.htm

Permission to copy (for users in the U.S.A) is available from the Copyright Clearance Center, http://www. copyright.com, email: info@copyright.com.

Advertising: Perspectives on Pollitics has a circulation of 16,000 . For information on advertising rates and mechanical requirements, contact Advertising Coordinator, Cambridge University Press, One Liberty Plaza, Floor 20, New York, NY 10006. (212) 337-5000

Composition: TNQ Books and Journals Pvt. Ltd., Chennai, India. Printing and Distribution: The Sheridan Press, Hanover, PA. 


\section{About APSA}

Founded in 1903, the American Political Science Association is the leading professional organization for the study of political science and serves more than 13,000 members in over 80 countries. With a range of programs and services for individuals, departments, and institutions, APSA brings together political scientists from all fields of inquiry, regions, and occupational endeavors within and outside academe in order to deepen our understanding of politics, democracy, and citizenship throughout the world.

The direct advancement of knowledge is at the core of APSA activities. We promote scholarly communication in political science through a variety of initiatives including publishing four distinguished journals: American Political Science Review, Perspectives on Politics, PS: Political Science \& Politics, and Journal of Political Science Education.

\section{Officers}

\section{PRESIDENT}

Kathleen Thelen

Massachusetts Institute of Technology

PRESIDENT-ELECT

Rogers Smith

University of Pennsylvania

\section{VICE-PRESIDENTS}

Evelyne Huber

University of North Carolina,

Chapel Hil

Pippa Norris

Harvard University \& University of Sydney

Gary Segura

University of California, Los Angeles

\section{Council}

2015-2018

Amaney Jamal

Princeton University

Brett Ashley Leeds

Rice University

James Mahoney

Northwestern University

Byron D'Andra Orey

Jackson State University

Bo Rothstein

University of Gothenburg

Cameron Thies

Arizona State University

Caroline Tolbert

University of Iowa

Carol Weissert

Florida State University

(2017-2018)

\section{PAST-PRESIDENT}

David Lake

University of California, San Diego

TREASURER

Thomas Pepinsky

Cornell University

\section{PROGRAM CO-CHAIRS}

Henry Farrell

The George Washington University

Anna Grzymala-Busse

Stanford University

EXECUTIVE DIRECTOR

Steven Rathgeb Smith

\section{Former APSA Presidents}

Frank J. Goodnow

Albert Shaw

Frederick N. Judson

James Bryce

A. Lawrence Lowell

Woodrow Wilson

Simeon E. Baldwin

Albert Bushnell Hart

W. W. Willoughby

John Bassett Moore

Ernst Freund

Jesse Macy

Munroe Smith

Henry Jones Ford

Paul S. Reinsch

Leo S. Rowe

William A. Dunning

Harry A. Garfield

James W. Garner

Charles E. Merriam

Charles A. Beard

William Bennett Munro

Jesse S. Reeves

John A. Fairlie

Benjamin F. Shambaugh

Edward S. Corwin

William F. Willoughby

Isidor Loeb

Walter Shepard

Francis W. Coker

Arthur N. Holcombe

Thomas Reed Powell

Clarence A. Dykstra

Charles Grove Haines

Robert C. Brooks

Frederic A. Ogg

William Anderson

Robert E. Cushman

Leonard D. White

John Gaus

Walter F. Dodd

Arthur W. MacMahon

Henry R. Spencer

Quincy Wright

James K. Pollock

Peter H. Odegard

Luther Gulick

Pendleton Herring

Ralph J. Bunche

Charles McKinley

Harold D. Lasswell

E. E. Schattschneider

V. O. Key, Jr.

R. Taylor Cole

Carl B. Swisher

Emmette S. Redford
Charles S. Hyneman

Carl J. Friedrich

C. Herman Pritchett

David B. Truman

Gabriel A. Almond

Robert A. Dahl

Merle Fainsod

David Easton

Karl W. Deutsch

Robert E. Lane

Heinz Eulau

Robert E. Ward

Avery Leiserson

Austin Ranney

James MacGregor Burns

Samuel H. Beer

John C. Wahlke

Leon D. Epstein

Warren E. Miller

Charles E. Lindblom

Seymour Martin Lipset

William H. Riker

Philip E. Converse

Richard F. Fenno

Aaron B. Wildavsky

Samuel P. Huntington

Kenneth N. Waltz

Lucian W. Pye

Judith N. Shklar

Theodore J. Lowi

James Q. Wilson

Lucius J. Barker

Charles O. Jones

Sidney Verba

Arend Lijphart

Elinor Ostrom

M. Kent Jennings

Matthew Holden, Jr.

Robert O. Keohane

Robert Jervis

Robert D. Putnam

Theda Skocpol

Susanne Hoeber Rudolph

Margaret Levi

Ira Katznelson

Robert Axelrod

Dianne M. Pinderhughes

Peter Katzenstein

Henry E. Brady

Carole Pateman

G. Bingham Powell, Jr.

Jane Mansbridge

John H. Aldrich

Rodney E. Hero

Jennifer Hochschild

David Lake

Christina Wolbrecht

University of Florida

University of Notre Dame 


\section{JOINTHE \\ AMERICAN \\ POLITICAL \\ SCIENCE \\ ASSOCIATION.}

Access the latest

scholarship in

political science.

Advance your career with

APSA scholarly teaching

resources $\&$ opportunities.

Learn more about APSA programs, grants, awards, etc.

Find jobs, postyour CV and access APSA career services.

Network with more than $6,000+$ political scientists at the Annual Meeting!
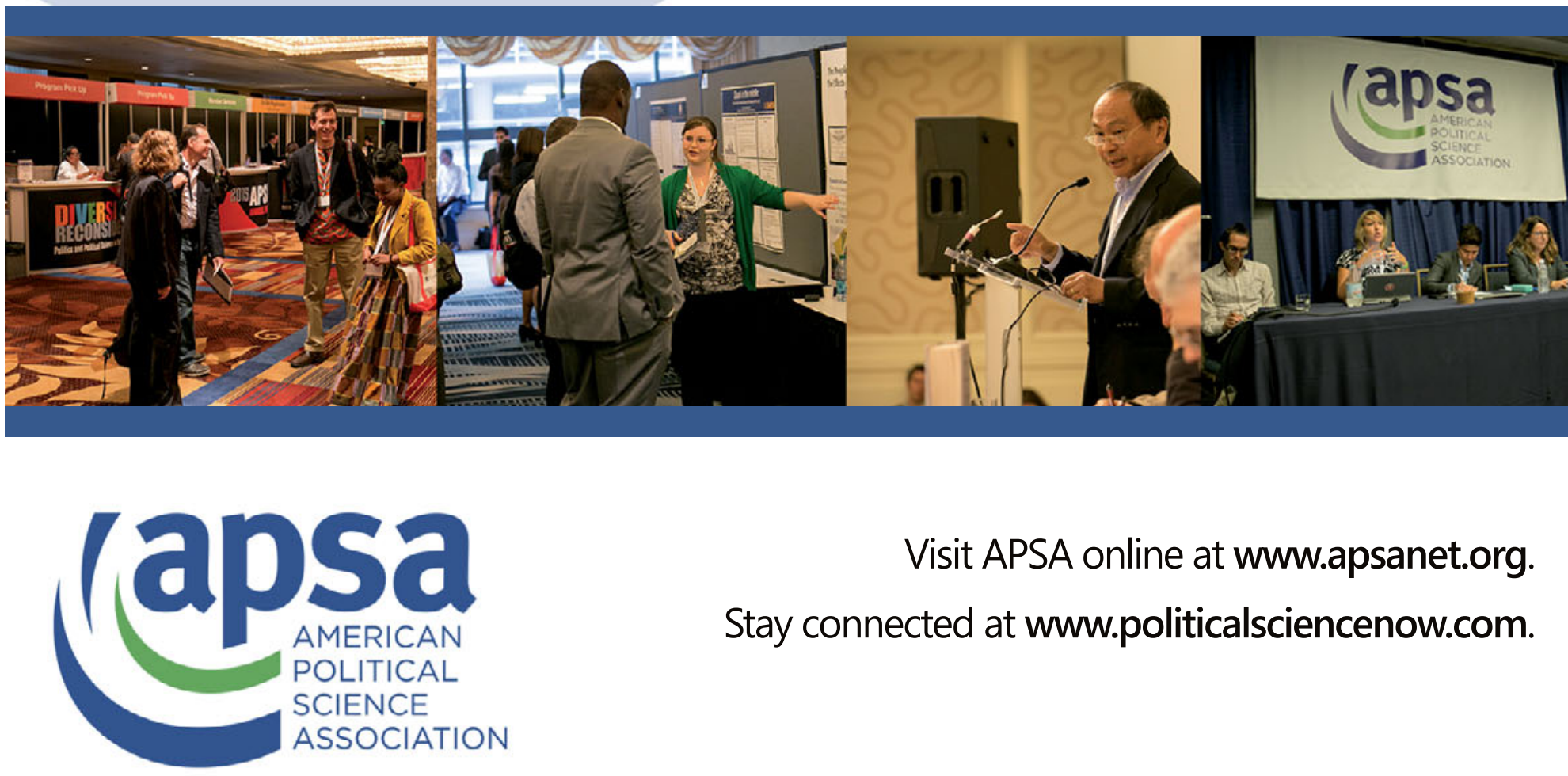

Visit APSA online at www.apsanet.org.

Stay connected at www.politicalsciencenow.com. 